\title{
Public health and the ultra-processed food and drink products industry: corporate political activity of major transnationals in Latin America and the Caribbean
}

\author{
Mélissa Mialon ${ }^{1, *}$ and Fabio da Silva Gomes ${ }^{2}$ \\ 'Departamento de Nutrição, Faculdade de Saúde Pública, Universidade de São Paulo, Av. Dr Arnaldo 715, \\ Cerqueira César, São Paulo, SP 03178-200, Brazil: ${ }^{2}$ Pan-American Health Organization/World Health \\ Organization, Washington, DC, USA
}

Submitted 25 September 2018: Final revision received 12 December 2018: Accepted 14 January 2019: First published online 12 March 2019

\begin{abstract}
Objective: To identify examples of the 'corporate political activity' (CPA) of the industry producing and selling ultra-processed food and drink products (UPP) in Latin America and the Caribbean.

Design: Searches were conducted on the national websites and social media accounts of large industry actors. Coding was deductive and based on a framework for classifying the CPA of the food industry.

Setting: Fifteen countries in Latin America and the Caribbean.

Participants: Twelve members of the International Food and Beverage Alliance (IFBA) and major trade associations and chambers of commerce in the region.

Results: During the current pilot study, more than 200 examples of CPA were found in Latin America and the Caribbean. The UPP industry lobbied governments during the development of national health policies. UPP companies tried to build alliances with health professionals, but also with communities where they operated and with policy makers. In addition, the UPP industry fought against regulation in court and proposed weaker alternatives to public health policies, such as self-regulation.

Conclusions: Food systems in low- and middle-income countries, including in Latin America and the Caribbean, are increasingly penetrated by the UPP industry. These countries are at risk of being influenced by the CPA strategies described in the present study. There is a need to further identify, monitor and evaluate the impact of these CPA strategies on public health policies and public opinion in the region, in order to develop mechanisms to effectively prevent such interference.
\end{abstract}

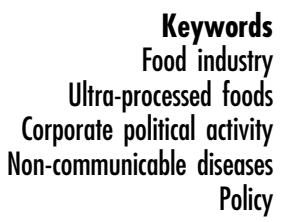

Keywords

rocessed foods

Corporate political activity

Policy
Ultra-processed food and drink products (UPP) are 'formulations made mostly or entirely from substances derived from foods and additives, with little if any intact (unprocessed or minimally processed) food' and their consumption has been linked with an increased risk of developing non-communicable diseases (NCD) ${ }^{(1)}$. Regulatory measures to control and prevent NCD have yet to be developed and implemented in many countries, in part due to the influence and opposition from the UPP industry ${ }^{(2,3)}$. Recently, UN Member States shared their concerns with regard to undue influence from this industry ${ }^{(4)}$. In response, the WHO is developing risk assessment, disclosure and management tools to safeguard against possible conflicts of interest in policy development and implementation of nutrition programmes ${ }^{(4,5)}$.

The term 'corporate political activity' (CPA) is defined as 'corporate attempts to shape government policy in ways favorable to the firm, ${ }^{(6)}$. CPA strategies are used by actors in the UPP, alcohol and tobacco industries when trying to influence public health policies and public opinion, thus delaying efforts to prevent and control $\mathrm{NCD}^{(7-12)}$. In the 1990 s, after litigation against the tobacco industry, internal documents were released to the public ${ }^{(13,14)}$. There is strong evidence, from the tobacco industry's own words, that CPA was successful in interfering with tobacco control $^{(10,12,15)}$. For many decades, CPA has undermined 
regulations that could have saved millions of lives. For the UPP industry, access to internal documents is limited. To fill this gap, in 2015, Mialon et al. developed an approach for identifying the CPA of the food industry at the country level, using publicly available information only ${ }^{(6)}$. This has been implemented in several parts of the world ${ }^{(7,8,16,17)}$. To date, there is, however, little evidence of the CPA of the UPP industry in Latin America and the Caribbean. Some charities or journalists have reported about these issues in Mexico or Colombia, for example, but the present study is the first systematic one of its kind in the region, to our knowledge $\mathrm{e}^{(18-20)}$.

The aim of the current pilot study was to identify examples of CPA strategies of the UPP industry in Latin America and the Caribbean.

\section{Methods}

The recommendations of Mialon et al. were used as follows ${ }^{(6)}$.

1. Selection of UPP industry actors: twelve members of the International Food and Beverage Alliance (IFBA), given it comprises the largest UPP corporations operating in the region ${ }^{(21)}$. See Appendix 1 for the list of industry actors included in the current pilot study.

2. Identification of trade associations in the UPP industry and chambers of commerce in the region (see Appendix 1).

3. Selection of a purposive sample of fifteen countries (alphabetical order): Argentina, Barbados, Brazil, Chile, Colombia, Costa Rica, Ecuador, El Salvador, Guatemala, Jamaica, Mexico, Panama, Peru, Trinidad and Tobago, and Uruguay. Table 1 presents, for each country, the policies implemented to promote healthy diets and reduce obesity.

4. For each industry actor and each country, identification of their official national websites and Twitter accounts (see Appendix 1). Other sources such as government or professionals' associations materials were not explored in the current pilot study.

5. Deductive coding of data, where examples of CPA were classified in one of the six categories presented in Appendix 2. These categories are not mutually exclusive, as some examples may belong to one strategy or another. Agreement about the categorisation of examples was reached after discussion between the two authors. An article published in September 2018 proposed a different terminology ${ }^{(9)}$. Data collection and analysis for the current pilot study took place in spring 2018, therefore this terminology was not used here. This new terminology could be used in future analyses of the CPA of the food industry.

6. Reporting of illustrative examples in the present study. Searches were limited to information published from
May 2017 to April 2018 inclusive. All data were collected in April 2018. Documents retrieved were in Spanish, Portuguese and English.

The current pilot study focused on public health and diet only (i.e. information collected did not include data on water scarcity and/or sustainability; employment/workforce). Information about baby food products and dietary supplements was not included, as these products are covered by public policies and international codes of conduct which strictly prohibit some CPA strategies. Sources of information related to specific products from the companies included in the current pilot study were not studied.

\section{Results}

In the fifteen countries analysed, more than 200 examples of CPA were found for the period May 2017-April 2018 inclusive. Most examples found for the present study were part of the 'information and messaging' and the 'constituency building' strategies. General Mills and Mars did not have Twitter accounts at the national level, and their respective national websites, in all fifteen countries, did not have information about their CPA.

Table 2 gives an overview of the different CPA strategies used by the twelve IFBA industry members, for each country.

In the following sections, illustrative examples of the CPA of the UPP industry in Latin America and the Caribbean are presented, with each example allocated a code starting with the letter A (see the online supplementary material for a full list of examples found during the present study).

\section{Information and messaging strategy}

Most examples found in the present study were categorised under this CPA strategy.

\section{Lobby policy makers}

On several occasions, UPP industry actors lobbied governments to try and influence their decisions when health regulation was discussed. This was the case in Costa Rica, Ecuador, Guatemala and Uruguay (A95-A98, A106-A110, A113-A116, A131, A133, A134, A222).

\section{Stress the economic importance of the industry}

Actors in the UPP industry also stressed their importance in the economy of the countries in which they operate, such as Argentina, Brazil, Colombia, Ecuador, Mexico, Peru, Trinidad and Tobago, and Uruguay (A3, A10, A13, A18, A35, A40, A70, A73, A80, A105, A112, A156, A164, A193, A197, A219, A223, A225). 
Table 1 Policies implemented to promote healthy diets and reduce obesity in the fifteen Latin American and Caribbean countries included in the current pilot study (data extracted from the WHO Global database on the Implementation of Nutrition Action ${ }^{(25)}$ )

\begin{tabular}{|c|c|c|c|c|c|c|c|}
\hline Country & $\begin{array}{l}\text { Food and nutrition labelling } \\
\text { standards and regulations }\end{array}$ & $\begin{array}{l}\text { Healthy food } \\
\text { environment } \\
\text { policies }\end{array}$ & $\begin{array}{l}\text { Fiscal } \\
\text { policies }\end{array}$ & $\begin{array}{l}\text { Regulation of marketing of foods } \\
\text { and non-alcoholic beverages }\end{array}$ & $\begin{array}{l}\text { Reformulation of } \\
\text { foods and } \\
\text { beverages }\end{array}$ & $\begin{array}{l}\text { Media campaigns on } \\
\text { healthy diets and nutrition }\end{array}$ & $\begin{array}{l}\text { Nutrition education and } \\
\text { counselling on healthy diets }\end{array}$ \\
\hline Argentina & $x$ & & & & $x$ & $x$ & $x$ \\
\hline Barbados & $x$ & $x$ & $x$ & & & $x$ & $x$ \\
\hline Brazil & $x$ & $x$ & & $\mathrm{x}$ & $x$ & $x$ & $x$ \\
\hline Chile & $x$ & $x$ & $x$ & $x$ & $x$ & $x$ & $x$ \\
\hline Colombia & $x$ & $x$ & & & $x$ & $x$ & $x$ \\
\hline Costa Rica & $x$ & $\mathrm{X}$ & & $\mathrm{X}$ & $x$ & $x$ & $x$ \\
\hline Ecuador & $x$ & $x$ & $x$ & $\mathrm{x}$ & $x$ & $x$ & $x$ \\
\hline El Salvador & $x$ & $x$ & & & & $x$ & $x$ \\
\hline Guatemala & $x$ & & & & & & $x$ \\
\hline Jamaica & $x$ & $\mathrm{x}$ & & & & $x$ & $x$ \\
\hline Mexico & $x$ & $x$ & $x$ & $X$ & $x$ & $x$ & $x$ \\
\hline Panama & $x$ & & & & & $x$ & $x$ \\
\hline Peru & $x$ & $\mathrm{x}$ & $x$ & $x$ & $x$ & $x$ & $x$ \\
\hline $\begin{array}{l}\text { Trinidad and } \\
\text { Tobago }\end{array}$ & $x$ & $x$ & & & $x$ & & $x$ \\
\hline Uruguay & $x$ & $\mathrm{x}$ & & $\mathrm{X}$ & $x$ & $x$ & $x$ \\
\hline
\end{tabular}


country included in the current pilot study ${ }^{\star}$

\begin{tabular}{|c|c|c|c|c|c|c|c|c|c|c|c|c|}
\hline \multirow[b]{2}{*}{ Country } & \multicolumn{12}{|c|}{ Company } \\
\hline & $\begin{array}{l}\text { Coca- } \\
\text { Cola }\end{array}$ & Danone & Ferrero & General Mills & Grupo Bimbo & Kellogg's & Mars & McDonald's & Mondelez & Nestlé & PepsiCo & Unilever \\
\hline Argentina & I, C, P & $\begin{array}{c}\text { No websites } \\
\text { available }\end{array}$ & No data & $\begin{array}{c}\text { No websites } \\
\text { available }\end{array}$ & $\begin{array}{c}\text { No websites } \\
\text { available }\end{array}$ & No data & No data & I, C & C & I, C & I, C & No data \\
\hline Barbados & $\mathrm{C}$ & & $\begin{array}{l}\text { No websites } \\
\text { available }\end{array}$ & & & $\begin{array}{c}\text { No websites } \\
\text { available }\end{array}$ & $\begin{array}{c}\text { No websites } \\
\text { available }\end{array}$ & $\begin{array}{c}\text { No websites } \\
\text { available }\end{array}$ & $\begin{array}{c}\text { No websites } \\
\text { available }\end{array}$ & $\begin{array}{c}\text { No websites } \\
\text { available }\end{array}$ & $\begin{array}{c}\text { No websites } \\
\text { available }\end{array}$ & $\begin{array}{l}\text { No websites } \\
\text { available }\end{array}$ \\
\hline Brazil & $\mathrm{I}, \mathrm{C}, \mathrm{P}$ & I, P & No data & No data & $\mathrm{I}, \mathrm{C}, \mathrm{P}$ & No data & No data & 1 & I & I, P & I, C & 1 \\
\hline Chile & $\mathrm{C}$ & $\begin{array}{l}\text { No websites } \\
\text { available }\end{array}$ & $\begin{array}{l}\text { No websites } \\
\text { available }\end{array}$ & $\begin{array}{l}\text { No websites } \\
\text { available }\end{array}$ & $\begin{array}{l}\text { No websites } \\
\text { available }\end{array}$ & & $\begin{array}{c}\text { No websites } \\
\text { available }\end{array}$ & $\mathrm{C}$ & $\begin{array}{c}\text { No websites } \\
\text { available }\end{array}$ & I, C & $\mathrm{I}, \mathrm{C}, \mathrm{L}$ & C \\
\hline Colombia & I & I, C & No data & & & C & & I, C & & I, C & $\mathrm{I}, \mathrm{C}, \mathrm{P}$ & I, C \\
\hline Costa Rica & $\mathrm{C}$ & $\begin{array}{l}\text { No websites } \\
\text { available }\end{array}$ & $\begin{array}{l}\text { No websites } \\
\text { available }\end{array}$ & & No data & $\begin{array}{c}\text { No websites } \\
\text { available }\end{array}$ & & $\mathrm{C}$ & & No data & $\begin{array}{c}\text { No websites } \\
\text { available }\end{array}$ & No data \\
\hline Ecuador & $\mathrm{C}$ & & No data & & $\begin{array}{l}\text { No websites } \\
\text { available }\end{array}$ & & & C & & I, C & & \\
\hline El Salvador & $\begin{array}{l}\text { No } \\
\text { data }\end{array}$ & & $\begin{array}{c}\text { No websites } \\
\text { available }\end{array}$ & & No data & & & No data & & $\mathrm{I}, \mathrm{C}, \mathrm{P}$ & & \\
\hline $\begin{array}{l}\text { Guatemala } \\
\text { Jamaica }\end{array}$ & & & & & $\begin{array}{c}\text { No websites } \\
\text { available }\end{array}$ & $\begin{array}{c}\text { No data } \\
\text { No websites } \\
\text { available }\end{array}$ & & $\begin{array}{c}\text { I, C } \\
\text { No websites } \\
\text { available }\end{array}$ & & $\begin{array}{l}\mathrm{I}, \mathrm{C} \\
\mathrm{I}, \mathrm{C}, \mathrm{P}\end{array}$ & & $\begin{array}{l}\text { No websites } \\
\text { available }\end{array}$ \\
\hline Mexico & $\mathrm{I}, \mathrm{C}, \mathrm{P}$ & & $\mathrm{I}, \mathrm{P}$ & No data & $P$ & I, C & No data & I, C & I & $\mathrm{I}, \mathrm{C}, \mathrm{P}$ & I, C & $\mathrm{I}, \mathrm{C}, \mathrm{P}$ \\
\hline Panama & $\begin{array}{l}\text { No } \\
\text { data }\end{array}$ & & $\begin{array}{l}\text { No websites } \\
\text { available }\end{array}$ & $\begin{array}{l}\text { No websites } \\
\text { available }\end{array}$ & No data & $\begin{array}{c}\text { No websites } \\
\text { available }\end{array}$ & $\begin{array}{l}\text { No websites } \\
\text { available }\end{array}$ & C & $\begin{array}{l}\text { No websites } \\
\text { available }\end{array}$ & $\mathrm{C}, \mathrm{P}$ & $\begin{array}{l}\text { No websites } \\
\text { available }\end{array}$ & No data \\
\hline Peru & $\mathrm{I}, \mathrm{C}, \mathrm{P}$ & & & & $\begin{array}{l}\text { No websites } \\
\text { available }\end{array}$ & No data & & I, C & & I, C & & \\
\hline $\begin{array}{c}\text { Trinidad and } \\
\text { Tobago }\end{array}$ & $\begin{array}{l}\text { No } \\
\text { data }\end{array}$ & & & & & $\begin{array}{c}\text { No websites } \\
\text { available }\end{array}$ & & No data & & I, C & & $\mathrm{I}, \mathrm{C}, \mathrm{P}$ \\
\hline Uruguay & I & & & & & No data & & C & & No data & 1 & No data \\
\hline
\end{tabular}

${ }^{*}$ For a better reading of this table, letters have been attributed to each strategy: $\mathrm{I}=$ information and messaging; $\mathrm{F}=$ financial incentives; $\mathrm{C}=$ constituency building; $\mathrm{P}=$ policy substitution; $\mathrm{L}=$ legal strategies; $\mathrm{O}=$ opposition fragmentation and destabilisation. 
Frame the debate on public health-and diet-related issues In most countries of the region, the UPP industry used messages and provided information that framed the debate in ways favourable to the companies. The UPP industry claimed to be part of the solution in the NCD epidemic (see e.g. A87, PepsiCo, Colombia). There was a strong emphasis on physical activity to maintain good health, while the role of UPP, central to the activities of food companies, was seldom mentioned.

Across the region, events for children were used to promote information about healthy eating. All industry actors included in the present study were members of the IFBA and therefore pledged to adopt the IFBA's commitments with regard to responsible marketing to children ${ }^{(22)}$. However, several companies did not comply with their own commitment and worked in schools. This was the case for the Programa Nestlé Niños Saludables (Nestlé Healthy Kids Program; A125, Nestlé, Ecuador) or the PespiCo ActivaRSE programme (A62, PepsiCo, Chile). In some instances, children were exposed to the brands of the companies (see e.g. A12, A72, A86, A120, A123, A1244, A203). In Brazil, as part of its 'Education and Nutrition Program', and after a visit to the Grupo Bimbo factory, pupils and their teachers were offered a kit that contained several products and material from the company (A25, Grupo Bimbo, Brazil).

Shape the evidence base on diet-and public health-related issues

There was evidence that the UPP industry tried to shape the evidence base on diet- and public health-related issues in Latin America and the Caribbean.

There was one example where a major trade association in the region tried to discredit scientific evidence on the role of ultra-processed food products, by qualifying the science of ideological or 'easy science' ( $v$. 'robust science'; A69). Industry actors also tried to shape evidence on dietrelated issues by engaging with public health professionals during scientific conferences. For example, a manager from Nestlé participated in the Diabetes Association Trinidad \& Tobago Expo 2017 (A211, Nestlé, Trinidad and Tobago).

\section{Financial incentives}

No publicly available evidence of use of the 'financial incentives' strategy by the UPP industry between May 2017 to April 2018 was found in the countries included in the current pilot study. This could be due to the fact that this type of information is usually found in official documents or registries from governments, which were not included in the present study. Another reason might be related to the fact that financial incentives are usually more evident during political campaigns prior to elections, and most countries analysed herein have not had any provincial or presidential elections during the study period.

\section{Constituency building strategy}

There were numerous examples of the 'constituency building' strategy in Latin America and the Caribbean, where the UPP industry tried to build relationships with health professionals, universities, communities and policy makers.

\section{Establish relationships with health professionals and universities}

In Latin America and the Caribbean, there was evidence that the UPP industry tried to establish relationships with health professionals and universities. For example, Unilever was a partner of the Instituto Nacional del Corazón (National Heart Institute) and the World Heart Federation (WHF; A89, Unilever, Colombia). In Mexico, Nestlé launched a Corporate Chair, specifically targeting nutrition education, with the Anáhuac University (A173, Nestlé, Mexico).

\section{Seek involvement in the community}

In all fifteen countries included in the present study, UPP industry actors sought involvement in the community in which they operated. Here again, some of these initiatives targeted children and included branded material (see e.g. the portions of cereal and snacks provided by Kellogg's to children and families; A78, Kellogg's, Colombia). In Ecuador, Nestlé, in partnership with other organisations, presented an event for children affected by a recent earthquake, during which they distributed a 'Nestlé kit' that consisted of seventeen Nestlé products (A122, Nestlé, Ecuador). Actors in the UPP industry also participated in programmes focusing on sustainability and water scarcity (see e.g. the cleaning of beaches in Peru; A189, Coca Cola, Peru).

\section{Establish relationships with policy makers}

For many countries in the region, there was evidence that actors in the UPP industry established relationships with policy makers (A2, A23, A28, A44, A68, A94, A102, A103, A111, A123, A132, A137, A138, A142, A148, A150, A151, A166-A171, A181, A184, A191 A19, A198, A204, A205, A221). For example, the Chilean programme CHILE CRECE SANO (Chile grows healthily) from Chilealimentos, a trade association, worked 'in conjunction with the FAO against obesity' (A44, Chilealimentos, Chile). On at least one occasion, members of CGAB (Camara Guatemalteca de Alimentos y Bebidas/Guatemalan Chamber of Food and Beverage) met with the Guatemalan Minister of Health (A132, CGAB, Guatemala). Some of these examples could also be categorised under the 'policy substitution' strategy.

\section{Legal strategies}

There was one example of a legal strategy and it was reported in the media, where PepsiCo and Kellogg's went 
to court, in Chile, to challenge a new regulation on food labelling and marketing (A66, PepsiCo and Kellogg's, Chile).

\section{Policy substitution strategy}

There was evidence of the 'policy substitution' strategy for many countries in Latin America and the Caribbean. These included, for example, the signature of a Memorandum of Understanding (MOU) between the industry and the government in Jamaica (A142, Nestlé, Jamaica), but also voluntary initiatives to reduce the level of sodium in food products, or to limit marketing to children (A5, A21, A22, A26, A31, A33, A38, A88, A100, A130, A144, A146, A155, A158, A177, A178, A183, A187, A195, A220). Here, some examples might also have been categorised under the 'constituency building' strategy.

\section{Opposition fragmentation and destabilisation strategy}

Three articles published by journalists ${ }^{(18,19,23)}$ reported on personal threats made against public health professionals who were working on the role of UPP in the NCD epidemic: a researcher in Brazil, the director of nutrition policy at Mexico's National Institute of Public Health and the head of a consumer advocacy group in Colombia (A43, A91, A227). No direct links were made with specific industry actors for these three cases.

\section{Discussion}

In Latin America and the Caribbean, there is evidence that the UPP industry used four of the six CPA strategies between May 2017 and April 2018. A majority of examples found for the present study were part of the 'information and messaging' and the 'constituency building' strategies. The UPP industry framed the debate by focusing on individuals when discussing NCD, with a particular emphasis on physical activity and personal responsibility. They never mentioned the role of UPP in this epidemic. They shaped the evidence base on diet- and public healthrelated issues by providing education materials to children and by organising events in schools, some of which might be considered as promotional activities. The UPP industry tried to build relationships with public health professionals, universities, communities and policy makers. There was, finally, one example of the 'legal strategies'.

There are some limitations with the current pilot study and the recommendations below might guide future studies that aim at capturing the full spectrum and extent of CPA used by the UPP industry at a regional or global level. First, it was not a detailed analysis of all CPA strategies, which was beyond the scope of the study, due to time and financial constraints. The pilot study was meant to set the ground for further work on that issue in the region. The reliance on publicly available information, and on certain sources only (industry material), certainly constrained the possible identification of some CPA practices. Future analyses could include other sources of information: governments' websites (Minister's diary disclosures, websites of commissions in charge of elections, etc.), professional associations' websites and the media, among others ${ }^{(6)}$. It is likely that practices such 'financial incentives' might only be observed during specific periods of time, such as elections. For these reasons, future studies should aim at an ideal time frame of 3-5 years or more, in order to capture these political changes. In addition, some some CPA strategies such as 'legal strategies', 'opposition, fragmentation and destabilisation' and 'policy substitution' may be employed when a regulatory policy is under discussion, or triggered by other specific political contexts. This could be verified in future studies. Finally, some practices, such as free lunches, phone calls or other interactions are usually not known to the public. Previous studies indicated that, in these cases, interviews with key actors in public health could help in identifying these practices ${ }^{(16,24)}$. Finally, future studies could assess the extent to which these CPA strategies influenced the policy process and public opinion, and classify them depending on their relative importance in undermining efforts to prevent and control NCD.

Economic objectives of actors in the UPP industry generally conflict with public health goals to prevent and control NCD. The examples presented in the current pilot study could raise awareness among public health professionals and policy makers (but also communities) about practices that have been used by other industries, particularly tobacco industry actors, for which there is clear evidence of their detrimental nature.

\section{Acknowledgements}

Financial support: M.M. received consultancy fees from the Pan-American Health Organization (PAHO). M.M. received a grant from the São Paulo Research Foundation (FAPESP), Brazil (grant number 2017/24744-0). The authors are solely responsible for the opinions, hypotheses and conclusions or recommendations expressed in this publication, and they do not necessarily reflect FAPESP nor PAHO's vision. F.S.G. is a staff member of PAHO. F.S.G. is responsible for the views expressed in this publication, and they do not necessarily represent the decisions or policies of PAHO. Conflict of interest: None. Authorship: M.M. and F.G. both formulated the research question and designed the study. M.M. carried it out, analysed the data and led the writing the article. F.G. critically revised the article. Ethics of buman subject 
participation: Not applicable, since the study did not involve human subjects.

\section{Supplementary material}

To view supplementary material for this article, please visit https://doi.org/10.1017/S1368980019000417

\section{References}

1. Monteiro CA, Cannon G, Moubarac JC et al. (2018) The UN Decade of Nutrition, the NOVA food classification and the trouble with ultra-processing. Public Health Nutr 21, 5-17.

2. World Health Organization (2013) Opening address at the 8th Global Conference on Health Promotion Helsinki, Finland, 10 June 2013 by Dr Margaret Chan Director-General of the World Health Organization. https://www.who.int/dg/ speeches/2013/health_promotion_20130610/en/ (accessed February 2019).

3. Moodie R, Stuckler D, Monteiro C et al. (2013) Profits and pandemics: prevention of harmful effects of tobacco, alcohol, and ultra-processed food and drink industries. Lancet 381, 670-679.

4. World Health Organization (2017) Executive Board, 142nd session, Provisional agenda item 4.6. EB142/23, 4 December 2017. Safeguarding against possible conflicts of interest in nutrition programmes. Draft approach for the prevention and management of conflicts of interest in the policy development and implementation of nutrition programmes at country level. Report by the Director General. http:// apps.who.int/gb/ebwha/pdf_files/EB142/B142_23-en.pdf (accessed February 2019).

5. World Health Organization (2012) Sixty-Fifth World Health Assembly, Provisional agenda item 12. A65/5, 25 April 2012. WHO reform. Consolidated report by the Director-General. http://apps.who.int/gb/ebwha/pdf_files/WHA65/A65_5-en. pdf (accessed February 2019).

6. Mialon M, Swinburn B \& Sacks G (2015) A proposed approach to systematically identify and monitor the corporate political activity of the food industry with respect to public health using publicly available information. Obes Rev 16, 519-530.

7. Mialon M \& Mialon J (2018) Analysis of corporate political activity strategies of the food industry: evidence from France. Public Health Nutr 21, 3407-3421.

8. Mialon M, Swinburn B, Allender S et al. (2016) Systematic examination of publicly-available information reveals the diverse and extensive corporate political activity of the food industry in Australia. BMC Public Health 16, 283.

9. Mialon M, Julia C \& Hercberg S (2018) The policy dystopia model adapted to the food industry: the example of the Nutri-Score saga in France. World Nutr 9, 109-120.

10. Savell E, Gilmore AB \& Fooks G (2014) How does the tobacco industry attempt to influence marketing regulations? A systematic review. PLoS One 9, e87389.

11. Savell E, Fooks G \& Gilmore AB (2016) How does the alcohol industry attempt to influence marketing regulations? A systematic review. Addiction 111, 18-32.

12. Ulucanlar S, Fooks GJ \& Gilmore AB (2016) The policy dystopia model: an interpretive analysis of tobacco industry political activity. PLoS Med 13, e1002125.

13. State of California, Department of Justice, Office of the Attorney General (2017) Master Settlement Agreement. http://oag.ca.gov/tobacco/msa (accessed February 2019).

14. University of California San Francisco (2017) Truth tobacco industry documents. https://www.industrydocumentsli brary.ucsf.edu/tobacco/ (accessed February 2019).
15. Gilmore AB, Fooks G, Drope J et al. (2015) Exposing and addressing tobacco industry conduct in low-income and middle-income countries. Lancet 385, 1029-1043.

16. Mialon M, Swinburn B, Wate J et al. (2016) Analysis of the corporate political activity of major food industry actors in Fiji. Global Health 12, 18.

17. Tselengidis A \& Östergren P-O (2018) Lobbying against sugar taxation in the European Union: analysing the lobbying arguments and tactics of stakeholders in the food and drink industries. Scand J Public Health. Published online: 5 July 2018. doi: 10.1177/1403494818787102.

18. Perlroth N (2017) Spyware's odd targets: backers of Mexico's soda tax. The New York Times, 11 February 2017. https://www.nytimes.com/2017/02/11/technology/hackmexico-soda-tax-advocates.html (accessed February 2019).

19. Jacobs A \& Richtel M (2017) She took on Colombia's soda industry. Then she was silenced. The New York Times, 13 November 2017. https://www.nytimes.com/2017/11/13/health/ colombia-soda-tax-obesity.html (accessed February 2019).

20. Calvillo A \& Székely A (2018) La trama oculta de la epidemia: obesidad, industria alimentaria y conflicto de interes. El Poder del Consumidor. https://elpoderdelconsumidor.org/ wp-content/uploads/2018/02/la-trama-oculta-d-la-epidemiaobesidad-2018.pdf (accessed February 2019).

21. The International Food and Beverage Alliance (2018) Our

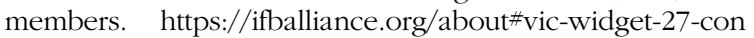
tainer-anchor (accessed February 2019).

22. The International Food and Beverage Alliance (2018) Our commitments: Responsible Marketing to Children - Global Policy on Marketing Communications to Children. https:// ifballiance.org/uploads/media/59eddc9fba341.pdf (accessed February 2019).

23. Peres J (2017) Big Food targets Brazilian researcher. OJoio e o Trigo, 19 December 2017. http://ojoioeotrigo.hospeda gemdesites.ws/2017/12/ultra-attack-brazilian-researcher-ta rgets-transnational-food/ (accessed February 2019).

24. Mialon M, Swinburn B, Allender S et al. (2017) 'Maximising shareholder value': a detailed insight into the corporate political activity of the Australian food industry. Aust $N Z J$ Public Health 41, 165-171.

25. World Health Organization (2018) Global database on the Implementation of Nutrition Action (GINA). https://extranet. who.int/nutrition/gina/en (accessed February 2019).

\section{Appendix 1}

\section{List of websites that were consulted for the current pilot study (countries and companies in alphabe- tical order)}

Argentina

- Coca Cola: https://www.cocacoladeargentina.com.ar/ bienestar

- Danone: no national website

- Ferrero: https://www.ferrero.com.ar/ (similar to other websites of the company in the region)

- General Mills: no national website

- Grupo Bimbo: no national website

- Kellogg's: https://www.kelloggs.com.ar/es_AR/home. html (similar to other websites of the company in the region)

- Mars: http://www.mars.com/argentina/es (little information online) 
- McDonald's: http://www.mcdonalds.com.ar/

- Mondelez: http://ar.mondelezinternational.com/home

- Nestlé: https://www.nestle.com.ar/

- PepsiCo: http://www.pepsicoargentina.com/

- Unilever: https://www.unilever.com.ar/ (similar to other websites of the company in the region)

- Asociación Argentina de Tecnólogos Alimentarios (AATA):

o https://twitter.com/AATA_Argentina

o http://www.alimentos.org.ar/

- ILSI: http://www.ilsi.org.ar/

- Coordinadora de Productores de Alimentos de Argentina (COPAL): http://copal.org.ar/alaiab/

- Cámara de Industriales de Productos Alimenticios (CIPA): http://www.cipa.org.ar

Barbados

- Coca Cola:

o http://www.thebhlgroup.com/page.cfm? $\mathrm{p}=$ subsidariesbarbadosbottling

o http://www.thebhlgroup.com/bhlhelp/

- Danone: no national website

- Ferrero: no national website

- General Mills: no national website

- Grupo Bimbo: no national website

- Kellogg's: no national website

- Mars: no national website

- McDonald's: no national website

- Mondelez: no national website

- Nestlé: no national website

- PepsiCo: no national website

- Unilever: no national website

- Barbados Chamber of Commerce and Industry (BBCI): http://www.barbadoschamberofcommerce.com/ (no specific information for the food industry)

\section{Brazil}

- Coca Cola: https://www.cocacolabrasil.com.br/

- Danone: http://corporate.danone.com.br/\#

- Ferrero: https://www.ferrero.com.br/ (no relevant information)

- General Mills: http://generalmills.com.br/ (little information online)

- Grupo Bimbo: https://www.bimbobrasil.com.br

- Kellogg's: http://www.kelloggs.com.br/pt_BR/home.html (similar to other websites of the company in the region)

- Mars: http://www.mars.com/brazil/pt/home (little information online)

- McDonald's: http://www.mcdonalds.com.br/

- Mondelez: https://br.mondelezinternational.com/home

- Nestlé: https://www.nestle.com.br/

- PepsiCo: http://www.pepsico.com.br/

- Unilever: https://www.unilever.com.br/ (similar to other websites of the company in the region)
- Associação Brasileira das Indústrias de Refrigerantes e de Bebidas Não Alcoólicas (ABIR): https://abir.org.br/ (little information online)

- Associação Brasileira das Indústrias da Alimentação (ABIA): https://www.abia.org.br/vsn/

- ILSI: http://ilsibrasil.org/

Chile

- Coca Cola: https://www.cocacoladechile.cl/

- Danone: no national website

- Ferrero: no national website

- General Mills: no national website

- Grupo Bimbo: no national website

- Kellogg's: http://www.kelloggs.cl/es_CL/home.html (similar to other websites of the company in the region)

- Mars: no national website

- McDonald's: http://www.mcdonalds.cl/

- Mondelez: no national website

- Nestlé:

o https://www.nestle.cl/

o https://www.nestle-contigo.cl/productos

- PepsiCo:

o http://www.pepsico.cl/home

o https://twitter.com/PepsiCoChile

- Unilever: https://www.unilever.cl/ (similar to other websites of the company in the region)

- Asociación Chilena de Ciencia y Tecnología en Alimentos (Sochital): http://sochital.com/

- ILSI: http://www.ilsisurandino.cl/sitio/

- Asociación de Empresas de Alimentos de Chile (CHILEALIMENTOS): http://www.chilealimentos.com/

\section{Colombia}

- Coca Cola: https://journey.coca-cola.com/homepage. co.html

- Danone: http://www.alqueria.com.co/prehome/

- Ferrero: https://www.ferreroladm.com/

- General Mills: no relevant information

- Grupo Bimbo: no relevant information

- Kellogg's: http://www.kelloggs.com.co/es_CO/home.html

- Mars: no national website

- McDonald's: http://www.mcdonalds.com.co/

- Mondelez: no national website

- Nestlé:

o https://www.corporativa.nestle.com.co/

o https://www.consumidor.nestle.com.co/

- PepsiCo: http://www.pepsico.com.co/

- Unilever: https://www.unilever-middleamericas.com/ (similar to other websites of the company in the region)

- Asociación Colombiana de Ciencia y Tecnología de Alimentos (ACTA): https://portal.acta.org.co

- Cámara de la Industria de Alimentos: http://www.andi. com.co/Home/Camara/16-industria-de-alimentos 
- Cámara de la Industria de Bebidas de la ANDI: http:// www.andi.com.co/Home/Camara/19-industria-de-bebidas (no specific information for the food industry)

\section{Costa Rica}

- Coca Cola: https://journey.coca-cola.com/homepage.cr. html (similar to other websites of the company in the region)

- Danone: no national website

- Ferrero: no national website

- General Mills: no national website

- Grupo Bimbo: see Guatemala

- Kellogg's: no national website

- Mars: no national website

- McDonald's: http://www.mcdonalds.co.cr/

- Mondelez: no national website

- Nestlé: see Ecuador

- PepsiCo: no national website

- Unilever: see Colombia

- Asociación de Tecnología Alimentaria de Costa Rica (Ascota): https://www.facebook.com/AscotaCR/

- ILSI: http://ilsimesoamerica.org/organizacion/

- Camara Costarricense de la Industria Aimentaria (CACIA): http://www.cacia.org/

Ecuador

- Coca Cola: https://journey.coca-cola.com/homepage. ec.html

- Danone: no national website

- Ferrero: see Colombia

- General Mills: no national website

- Grupo Bimbo: no national website

- Kellogg's: no national website

- Mars: no national website

- McDonald's: http://www.mcdonalds.com.ec/

- Mondelez: no national website

- Nestlé: https://ww1.nestle.com.ec/

- PepsiCo: no national website

- Unilever: see Colombia

- Asociación Nacional de Fabricantes de Alimentos y Bebidas (ANFAB): https://anfab.com/wp/

- ILSI: http://ilsinorandino.org/

- Asociación de Industrias de Bebidas No Alcohólicas del Ecuador (AIBE):

o https://twitter.com/AIBE_EC

o http://www.aibe.ec

- Cámara de Industrias y Producción (CIP): https://twitter. com/CamaraCIP

- Cámara de Industrias de Guayaquil: https://twitter.com/ Industriasgye

- Camara de Comercio de Quito: https://twitter.com/ lacamaradequito (nothing found for the food industry)

\section{El Salvador}

- Coca Cola: https://journey.coca-cola.com/homepage. sv.html (similar to other websites of the company in the region)

- Danone: no national website

- Ferrero: no national website

- General Mills: no national website

- Grupo Bimbo: see Guatemala

- Kellogg's: no national website

- Mars: no national website

- McDonald's: no national website

- Mondelez: no national website

- Nestlé:

o https://www.nestle-centroamerica.com/home

o https://twitter.com/nestlecam

o https://www.nestleagustoconlavida.com/

- PepsiCo: no national website

- Unilever: see Colombia

- Cámara de Comercio e Industria de El Salvador: http:// www.camarasal.com/ (nothing found for the food industry)

\section{Guatemala}

- Coca Cola: https://journey.coca-cola.com/homepage.gt. html (similar to other websites of the company in the region)

- Danone: no national website

- Ferrero: no national website

- General Mills: no national website

- Grupo Bimbo:

o http://bimboamericacentral.com/ (a whole website on nutrition: http://www.nutriciongrupobimbo. $\mathrm{com} /$ )

o https://twitter.com/nutricionbimbo (not studied in the current pilot study)

- Kellogg's: http://www.kelloggs.com.gt/es_GT/home. html (similar to other websites of the company in the region)

- Mars: no national website

- McDonald's: https://mcdonalds.com.gt/

- Mondelez: no national website

- Nestlé: see El Salvador

- PepsiCo: no national website

- Unilever: see Colombia

- Gremial de Fabricantes de Alimentos (GREFAL): no presence online

- Cámara de Industria de Guatemala (CIG): http://cig. industriaguate.com/

- Camara Guatemalteca de Alimentos y Bebidas (CGAB): https://es-la.facebook.com/cgab.org.gt/ (nothing found for the food industry) 
Jamaica

- Coca Cola: no national website

- Danone: no national website

- Ferrero: no national website

- General Mills: no national website

- Grupo Bimbo: no national website

- Kellogg's: no national website

- Mars: no national website

- McDonald's: no national website

- Mondelez: no national website

- Nestlé: https://www.nestle.com.jm/

- PepsiCo: no national website

- Unilever: no national website

Mexico

- Coca Cola (Facebook and all websites need to be further explored, lot of potential information):

o http://www.coca-colacompany.com/profiles/jour ney-mexico

o https://twitter.com/somoscocacola

o https://www.coca-colamexico.com.mx/

o https://www.coca-colafemsa.com/

- Danone: http://www.grupodanone.com.mx

- Ferrero: https://www.ferrero.com.mx/

- General Mills: http://generalmills.mx/ (little information online)

- Grupo Bimbo: no national website

- Kellogg's:

o http://www.kelloggs.com.mx/es_MX/home.html o https://www.hablandoconkelloggs.com/es_MX/

- Mars: http://www.mars.com/mexico/es (little information online)

- McDonald's: http://www.mcdonalds.com.mx/

- Mondelez: https://mx.mondelezinternational.com/home

- Nestlé:

o https://www.nestle.com.mx/

o https://www.nutrir-nestle.com.mx/

- PepsiCo: http://www.pepsico.com.mx/ (similar to other websites of the company in the region)

- Unilever: https://www.unilever.com.mx/ (similar to other websites of the company in the region)

- Industria Refresquera Mexicana (ANPRAC): http:// anprac.org.mx/

- Consejo Mexicano de la Industria de Productos de Consumo (ConMexico): https://conmexico.com.mx/sitio/

- ILSI: http://ilsi.org/mexico/ilsi-mexico/fundamentos/ (no relevant information)

\section{Panama}

- Coca Cola: https://journey.coca-cola.com/homepage. pa.html (similar to other websites of the company in the region)
- Danone: no national website

- Ferrero: no national website

- General Mills: no national website

- Grupo Bimbo: see Guatemala

- Kellogg's: no national website

- Mars: no national website

- McDonald's: http://www.mcdonalds.com.pa/

- Mondelez: no national website

- Nestlé: see El Salvador

- PepsiCo: no national website

- Unilever: see Colombia

- Colegio Panameño de Ciencia y Tecnología de Alimentos (COPCyTA): http://copcyta.org.pa/

- Agro\&Food Integrity: http://www.afi.com.pa/

- Cámara de Comercio, Industrias y Agricultura de Panamá (CCIAP) (nothing found for the food industry):

o https://twitter.com/CCIYAP

o https://www.panacamara.com/

Peru

- Coca Cola: https://www.cocacoladeperu.com.pe/

- Danone: no national website

- Ferrero: no national website

- General Mills: no national website

- Grupo Bimbo: no national website

- Kellogg's: http://www.kelloggs.com.pe/es_PE/home. html (similar to other websites of the company in the region)

- Mars: no national website

- McDonald's: http://www.mcdonalds.com.pe/

- Mondelez: no national website

- Nestlé:

o https://www.nestle.com.pe/

o https://www.nestlebebe.es/mil-primeros-dias\#

- PepsiCo: no national website

- Unilever: https://www.unilever.com.pe/ (similar to other websites of the company in the region)

- Asociación de bebidas y refrescos sin alcohol del Perú (ABRESA): http://abresa.pe/

\section{Trinidad and Tobago}

- Coca Cola: only a commercial website

- Danone: no national website

- Ferrero: no national website

- General Mills: no national website

- Grupo Bimbo: no national website

- Kellogg's: no national website

- Mars: no national website

- McDonald's: http://www.mcdonalds.com.tt/ (no relevant information)

- Mondelez: no national website

- Nestlé: https://www.nestle.tt/

- PepsiCo: no national website

- Unilever: https://www.unilever.tt/ 
Uruguay

- Coca Cola: https://www.coca-coladeuruguay.com.uy/

- Danone: no national website

- Ferrero: no national website

- General Mills: no national website

- Grupo Bimbo: no national website

- Kellogg's: http://www.kelloggsuruguay.com.uy/es_UY/ home.html (similar to other websites of the company in the region)

- Mars: no national website

- McDonald's:

o http://www.mcdonalds.com.uy/

o http://www.arcosdorados.com/

- Mondelez: no national website

- Nestlé: https://www.nestle.com.uy/ (similar to other websites of the company in the region)
- PepsiCo: http://www.pepsico.com.uy/uruguay/index. html

- Unilever: https://www.unilever.com.uy/ (similar to other websites of the company in the region)

- Sociedad Uruguaya de Ciencia y Tecnologia de Alimentos (SUCTAL): no presence online

- Cámara Industrial de Alimentos (CIALI): http://www. camaradealimentos.com/

Americas region

- Asociación Latinoamericana y del Caribe de Ciencia y Tecnología de Alimentos: http://alaccta.org/

- Grupo Regional para Latinoamérica y el Caribe del Consejo Internacional de Asociaciones de Bebidas: https://twitter.com/Icba_Latam

- Alianza Latinoamericana de Asociaciones de la Industria de Alimentos y Bebidas (ALAIAB): http://www.alaiab. com/

\section{Appendix 2}

Description of corporate political activity (CPA) strategies and related practices of the ultra-processed food and drink products industry (from Mialon et al. ${ }^{(6)}$ )

\begin{tabular}{|c|c|}
\hline CPA strategy & Description of CPA practices \\
\hline Information and messaging & $\begin{array}{l}\text { The information strategy includes practices through which the industry disseminates information that is } \\
\text { likely to be beneficial to its activities in order to influence public health-related policies and outcomes in } \\
\text { ways that are in its favour. This strategy includes: lobbying policy makers; stressing the economic } \\
\text { importance of the industry; promoting deregulation; framing the debate on diet- and public health- } \\
\text { related issues; and shaping the evidence base on diet and public health-related issues }\end{array}$ \\
\hline Financial incentives & $\begin{array}{l}\text { Through the financial incentives strategy, the industry provides funds, gifts and other incentives to } \\
\text { politicians, political parties and other decision makers }\end{array}$ \\
\hline Constituency building & $\begin{array}{l}\text { The aim of the constituency building strategy is to gain the favour of public opinion as well as other key } \\
\text { stakeholders, such as the media and the public health community. This strategy includes: establishing } \\
\text { relationships with key opinion leaders and health organisations; seeking involvement in the } \\
\text { community; establishing relationships with policy makers; and establishing relationships with the } \\
\text { media }\end{array}$ \\
\hline Legal strategies & $\begin{array}{l}\text { In this category, the industry uses legal action (or the threat thereof) against public policies or opponents. } \\
\text { The industry may also attempt to influence the development of trade and investment agreements in its } \\
\text { favour }\end{array}$ \\
\hline Policy substitution & $\begin{array}{l}\text { When threatened by regulation, the industry proposes alternatives, such as voluntary initiatives or self- } \\
\text { regulation }\end{array}$ \\
\hline $\begin{array}{l}\text { Opposition fragmentation and } \\
\text { destabilisation }\end{array}$ & $\begin{array}{l}\text { The opposition fragmentation and destabilisation strategy refers to practices employed by the industry to } \\
\text { fragment and destabilise groups or individuals that have criticised or are likely to oppose a company's } \\
\text { products or practices or policies that may adversely impact on the company }\end{array}$ \\
\hline
\end{tabular}

